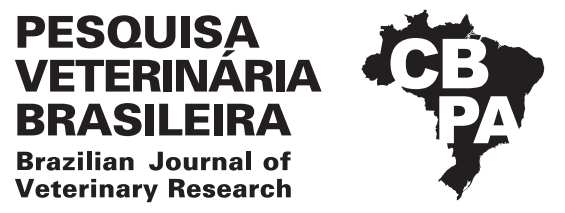

Pesq. Vet. Bras. 38(8):1511-1517, agosto 2018 DOI: 10.1590/1678-5150-PVB-5233

Original Article

Animais de Produção/Livestock Diseases

ISSN 0100-736X (Print)

ISSN 1678-5150 (Online)

\title{
MALDI-TOF MS as a tool for the identification of Vibrio alginolyticus from Perna perna mussels (Linnaeus, 1758) ${ }^{1}$
}

\begin{abstract}
Greiciane F. Bronzato ${ }^{2}$, Marcelo S. Oliva², Marisol G. Alvin², Bruno R. Pribul', Dália P. Rodrigues ${ }^{3}$, Shana M.O. Coelho ${ }^{2}$, Irene S. Coelho ${ }^{2}$ and Miliane M.S. Souza ${ }^{2 *}$

ABSTRACT.- Bronzato G.F., Oliva M.S., Alvin M.G., Pribul B.R., Rodrigues D.P., Coelho S.M.O., Coelho I.S. \& Souza M.M.S. 2018. MALDI-TOF MS as a tool for the identification of Vibrio alginolyticus from Perna perna mussels (Linnaeus, 1758). Pesquisa Veterinária Brasileira 38(8):1511-1517. Departamento de Microbiologia e Imunologia Veterinária, Universidade Federal Rural do Rio de Janeiro, BR-465 Km 7, Seropédica, RJ 23897-970, Brazil. E-mail: miliane@ufrrj.br

Vibrio species are ubiquitous in aquatic environments, including coastal and marine habitats. Vibrio alginolyticus is an opportunistic pathogen for fish, crustaceans and mussels and their identification by biochemical tests may be impaired due their nutritional requirements. The study used Matrix-Assisted Laser Desorption/Ionization Time-of-Flight Mass Spectrometry (MALDI-TOF MS) to identify 49 Vibrio spp. isolates associated with mussels (Perna perna) from different locations along the Rio de Janeiro coast. The rpoA gene was used as a genus-specific marker of Vibrio spp. and was positive in all 209 isolates. MALDI-TOF MS confirmed 87.8\% of $V$. alginolyticus when compared to the results of the biochemical tests. Four isolates were identified as Shewanella putrefaciens $(8.16 \%)$ and one was identified as V. parahaemolyticus $(2.0 \%)$. Just one isolate was not identified by this technique $(2.0 \%)$. The pyrH sequencing confirmed $75 \%$ of the proteomic technique results. MALDI-TOF MS is an excellent option for characterization of bacterial species, as it is efficient, fast and easy to apply. In addition, our study confirms its high specificity and sensitivity in these marine bacteria identification.
\end{abstract}

INTEX TERMS: MALDI-TOF MS, mitiliculture, Vibrio alginolyticus, Perna perna, mussels.

RESUMO.- [MALDI-TOF MS como ferramenta na identificação de Vibrio alginolyticus isolados de mexilhões Perna perna (Linnaeus, 1758).] Espécies de Vibrio são ubiquitárias em ambientes aquáticos, incluindo habitats costeiros e marinhos. A espécie Vibrio alginolyticus é oportunista para peixes, crustáceos e moluscos e a sua identificação através de testes bioquímicos pode ter a qualidade prejudicada devido às suas exigências nutricionais. 0 presente estudo utilizou Espectrometria de Massa por Tempo de Vôo de

\footnotetext{
${ }^{1}$ Received on July 20, 2017.

Accepted for publication on September 7, 2017.

${ }^{2}$ Departamento de Microbiologia e Imunologia Veterinária, Universidade Federal Rural do Rio de Janeiro (UFRRJ), BR- $465 \mathrm{Km} \mathrm{7,} \mathrm{Seropédica,} \mathrm{RJ}$ 23897-970, Brazil. E-mail: marisolalvimg@gmail.com; *Corresponding author: miliane@ufrrj.br

${ }^{3}$ Laboratório de Enterobactérias, Departamento de Bacteriologia, Pavilhão Rocha Lima, Instituto Oswaldo Cruz, Fiocruz, Av. Brasil 4365, Manguinhos, Rio de Janeiro, RJ 21045-900, Brazil.
}

Ionização/Desorção por Laser Assistida por Matriz (MALDI-TOF MS) para identificar diferentes espécies de Vibrio provenientes de mexilhões (Perna perna) coletados em diferentes locais ao longo da costa do Rio de Janeiro. 0 gene rpoA foi utilizado como um marcador gênero-específico de Vibrio spp. sendo positivo em todos os 209 isolados. MALDI-TOF MS confirmou 87,75\% de $V$ alginolyticus quando comparados com os resultados dos testes bioquímicos. Quatro isolados foram identificados como Shewanella putrefaciens $(8,16 \%)$, um como V. parahaemolyticus $(2,0 \%)$ e apenas um $(2,0 \%)$ não foi identificado pela técnica proteômica. E o sequenciamento do pyrH confirmou $75 \%$ dos resultados da técnica proteomica. MALDI-TOF MS tem sido considerada uma excelente opção para a caracterização bacteriana, por ser eficiente, rápida, de fácil aplicação e este estudo confirmou a sua elevada especificidade e sensibilidade na identificação de bactérias marinhas.

TERMOS DE INDEXAÇÃO: MALDI-TOF MS, militicultura, Vibrio alginolyticus, Perna perna, mussels. 


\section{INTRODUCTION}

Vibrio species are Gram-negative and halophilic bacteria comprising a highly diverse metabolic group of autochthons in the marine environment (Makino et al. 2003, Haley et al. 2010). The Cholera and Vibrio Illness Surveillance System (COVIS) of the Centers for Disease Control and Prevention (CDC), and the World Health Organization (WHO) considers pathogenic Vibrio species to be a public health threat and annually reports the number of human infections during Vibrio outbreaks. (vibriosis by pathogenic Vibrio species including V. alginolyticus, V. parahaemolyticus, V. vulnificus, V. mimicus and other Vibrio species; Cholera due to toxigenic V. cholerae) (Scallan et al. 2011, CDC 2012, WHO 2013,2014).

Vibrio alginolytius belongs to the saprophytic microbiota of several marine inhabitants and has wide geographical distribution. It is considered a ubiquitous organism in seawater and an opportunistic pathogen for fish, shellfish, crustaceans, coral reefs, mussels and it has also been reported causing otitis and wounds infections in humans (Cavallo \& Stabili 2002, Sganga et al. 2009, Wang et al. 2012, Zhenyu et al. 2013, Kong et al. 2015). As reported, the temperature, salinity, $\mathrm{pH}$, and starvation are the primary environmental factors of epidemic vibriosis in aquaculture (Li \& Chen 2008, Yi et al. 2008, Yeh et al. 2010, López-Hernández et al. 2015). Outbreaks of infections by Vibrio alginolytius in aquiculture have been reported in the United States, Spain, Mexico, Japan and China (Cavallo \& Stabili 2002).

Global warming is implicated in the increase of average ocean temperature, which favors the incidence of unseasonal V. alginolyticus outbreaks (Sganga et al. 2009). The pathogenesis and epidemiology of $V$. alginolyticus infections are under investigation. Nonetheless, it is clearly correlated with the rise of seafood consumption (Wang \& Chen 2005, Wang et al. 2008, Yoder et al. 2008).

The close relation of Vibrio alginolyticus to others species, such as V. parahaemolyticus, requires additional techniques for its differentiation. Also, this species undergoes significant genetic, physiological and morphological changes due to laboratorial conditions or in nutrient-restricted environments (Srinivasan \& Kjelleberg 1998, Bauer \& Rørvik 2007). The great variability of biochemical characteristics of Vibrio species makes it difficult to standardize an accurate phenotypic identification (Thompson et al. 2004, Tarr et al. 2007). For these reasons, it is necessary to develop more specific, rapid, and sensitive methods for Vibrio species identification.

Different modern molecular technologies that analyses biological materials have increased potentials for the detection, identification and enumeration of bacterial strains in water, food, clinical and environmental samples (Gilbride et al. 2006). Molecular techniques such as restriction fragment length polymorphism (RFLP), 16S rDNA gene sequencing and pulsed-field gel electrophoresis (PFGE) are discriminating and informative for measuring strain relatedness, diversity and can profitably be used to trace epidemiological sources (Sur et al. 2007).

Recently, proteomic technologies have been widely used for research into microbial gene expression and physiology. Even considering the recent advances in sequencing complete bacterial genomes, proteomic analysis provides information not available solely from genomic analysis (Van Schaik \& Willems 2010, Cash 2011). This method can complement gene sequencing, yielding unique biochemical fingerprints for species sub-typing (Emami et al. 2012).

Mass spectrometry (MS) is a technique based in the analysis of ionized molecules in a gaseous phase. Measurements of the mass are obtained by measuring the acceleration of ions in an electric field. Since proteins and peptides are not volatile, the generation of a sufficiently high concentration of intact ionized molecules is a big challenge (Stryer et al. 2007, Penque 2009). Lasch et al. (2009) described a proteomic technique using whole cells to detect reproducible standards of microbial protein in order to support phenogenotypical assays. Several reports have shown that MALDI-TOF MS is an option for the identification of pathogenic bacteria at the species (Carbonnelle et al. 2007, Barbuddhe et al. 2008, Dieckmann et al. 2008, Ilina et al. 2009, Nagy et al. 2009).

The minimal sample preparation, sample acquisition and the speed of the data acquisition combined with its potential for high-throughput sample automation may turn MALDI-TOF MS into a valuable effective method (Bruyne et al. 2011).

In this study, we analyzed MALDI-TOF MS as a tool for reliable identification of Vibrio alginolyticus, considering its importance in human and animal health.

\section{MATERIALS AND METHODS}

Sampling. Mussels of the Perna species were collected at three different times and places in the state of Rio de Janeiro, totalizing seven different sampling being three from the rocks of the Santana Archipelago, Macae, two from mariculture longline in the Bay of Ilha Grande, Angra dos Reis and finally, two collections were made on the beach in Arraial do Cabo, Rio de Janeiro (Fig.1). In each colletion were obtained 2 lots containing 25 adult mussels with closed valves and the same size as used commercially (greater than $6 \mathrm{~cm}$ ). The mussels were washed individually with brush in running drinking water to remove the dirt. During this process were rejected the animals with open valves, totalizing two hundred samples of mussels (Perna perna). The samples were placed in polyethylene boxes and transported at $6-10^{\circ} \mathrm{C}$ to the Veterinary Bacteriology Laboratory of Federal Rural University of Rio de Janeiro. The samples were properly kept in polyethylene boxes. They were identified, placed in an ice chest and transported in temperature conditions between $6-10{ }^{\circ} \mathrm{C}$ to the Veterinary Bacteriology Laboratory of Federal Rural University of Rio de Janeiro. The preparation of the mussels such as the removal of dirt, shell openings, crushing of the body mass, removal of the intravalvar liquid and inoculation were performed according to the protocol described by FDA (2004).

Microbiological analysis. The body mass and intravalvular liquid were shaked in beaker to held crushing of the solid parts and promotes homogenization of the material. Aiming detect Vibrio alginolyticus a 25 -gram sample was added to $225 \mathrm{~mL}$ of alkaline peptone water (APW) containing 1\% NaCl. Serial dilution of each sample was performed until $10^{-2}$ dilution in APW, used as enrichment broth, and the samples were incubated at $37^{\circ} \mathrm{C}$ for 18 hours. After that, they were inoculated in plates containing Thiosulfate Citrate Bile Sucrose agar (TCBS) with the addition of 1, 2 and $3 \% \mathrm{NaCl}$ and incubated at $37^{\circ} \mathrm{C}$ for 18 to 24 hours (FDA, 2004). Vibrio alginolyticus isolates was considered as those that presented yellow colonies characteristic of sucrose fermentation. These isolates were submitted to biochemical tests for species confirmation. Five to ten colonies from each plate were inoculated into tubes containing nutrient agar, LIA (lysine iron agar) and KIA (Kligler iron agar), along with $1 \% \mathrm{NaCl}$, and incubated at $37^{\circ} \mathrm{C}$ for 24 hours for differential diagnosis between Vibrio spp. 


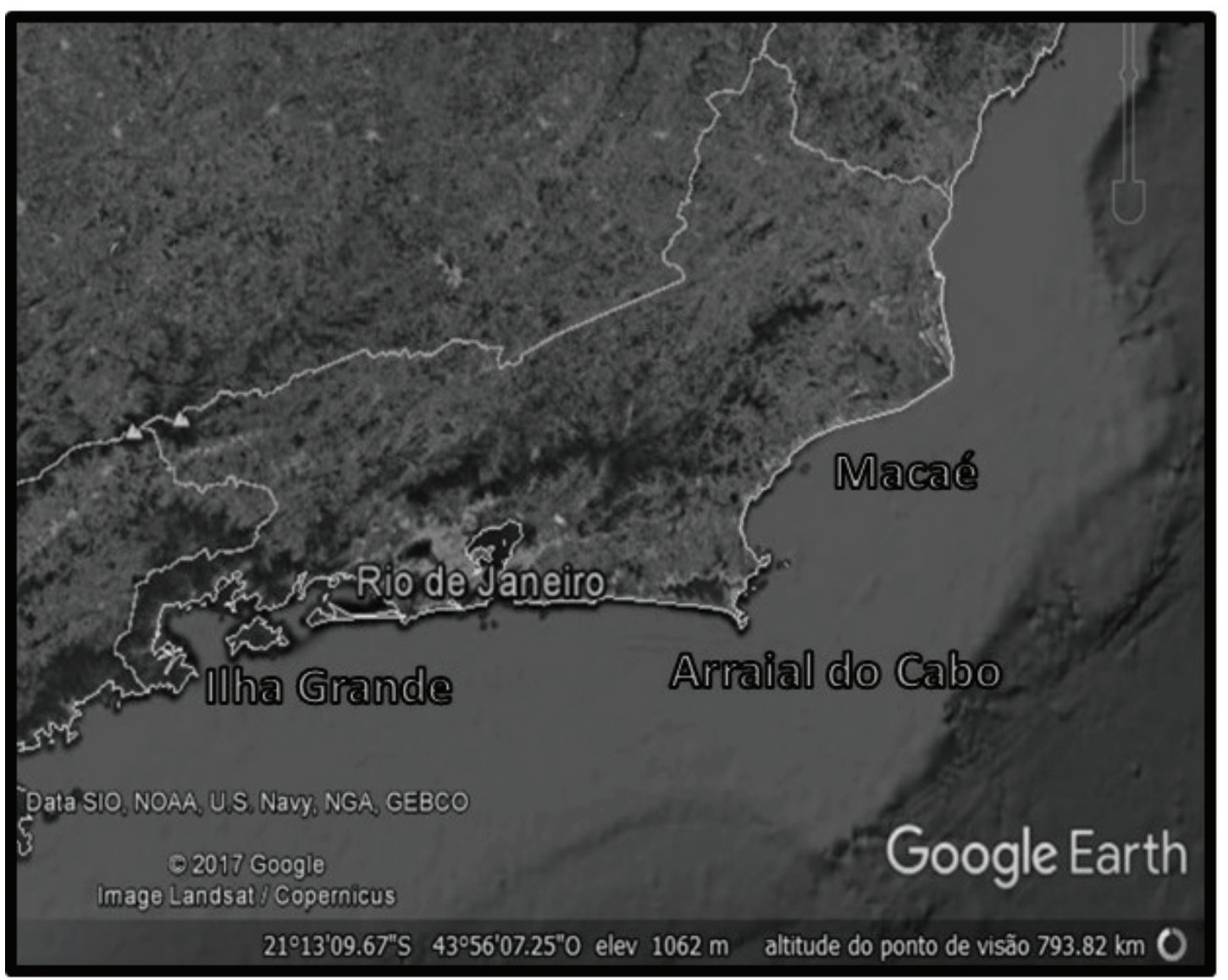

Fig.1. Map of the State of Rio de Janeiro, indicating the three regions studied.

and Enterobacteriaceae members. Additionally, the isolates were submitted to the cytochrome-oxidase test to distinguish Vibrio spp. from Enterobacteriaceae members (Koneman et al. 2008). Vibrio species identification was performed through biochemical tests based on exposure to two different concentrations $(10 \mu \mathrm{g}$ and $150 \mu \mathrm{g})$ of vibriostatic agent $0 / 129$ resistance (2,4 diamine-6,7 diisopropilpteridine); production of ortho-nitrophenyl- $\beta$-galactoside (ONPG); production of acetoine by using the Voges-Proskauer test; fermentation of glucose, sucrose, arabinose, lactose, cellobiose, mannitol, maltose and mannose; presence of lysine and ornithine decarboxylase; presence of arginine dehydrogenase; gelatin hydrolysis; presence of halophilia in different $\mathrm{NaCl}$ APW concentrations $(0 \%, 3 \%, 6 \%$, $8 \%$ and $10 \%$ ); motility observation, indole production; and nitrate reduction (Sewell 2002). Vibrio alginolyticus ATCC 17749 was used as reference strain.

Genetic analysis. Polymerase chain reaction for $r p o A$ gene was carried out to confirm Vibrio spp. identification. Bacterial DNA extraction was performed by thermal lysis according to the method proposed by Dalmasso et al. (2009). The PCR was performed in a final volume of $20 \mu \mathrm{l}$ containing $10 \mathrm{X}$ buffer $(10 \mathrm{mmol}$ $\mathrm{l}^{-1}$ Tris $\mathrm{HCl}, \mathrm{pH} 9.0,50 \mathrm{mM} \mathrm{KCl}$, and $0.1 \%$ Triton $\left.\mathrm{X}-100\right), 2.5 \mathrm{mmol}$ $\mathrm{l}^{-1} \mathrm{MgCl}_{2}, 0,3 \mathrm{mmol} \mathrm{l}^{-1}$ of each primer $5^{\prime}$-AATCAGGCTCGGGCCCT-3' and $5^{\prime}$ GCAATTTT(A/G)TC(A/G/T)AC(C/T)GG-3' (Bioneer, Seoul, Korea South), $0.2 \mathrm{mmol}^{-1} \mathrm{dNTP}$ (Fermentas), $1 \mathrm{U}$ of Taq polymerase (Fermentas) and $5 \mu$ l the DNA extract. Amplicons of $242 \mathrm{bp}$ were detected by $1.5 \%$ agarose gel, stained with SYBR green (Invitrogen) and examined under a UV transilluminator (UvTrans) and then documented by the program QuantiOne $\left(\operatorname{BioRad}^{\circledR}\right)$ using molecular weight markers of $100 \mathrm{bp}$ (Fermentas).

MALDI-TOF MS technique. The samples were inoculated in BHI agar at $37^{\circ} \mathrm{C}$ for $24 \mathrm{~h}$ and each culture was transferred to a microplate (96 MSP, Bruker - Billerica, USA). The bacterial sediment was covered by a lysis solution (70\% formic acid, Sigma-Aldrich). Futhermore, a 1- $\mu \mathrm{L}$ aliquot of matrix solution (alpha-ciano-4-hidroxi-cinamic acid diluted in 50\% acetonitrile and $2.5 \%$ trifluoracetic acid, Sigma-Aldrich) was added to each sediment. The spectra of each sample were generated in a mass spectrometer (MALDI-TOF LT Microflex, Bruker) equipped with a 337-nm nitrogen laser in a linear path, controlled by the FlexControl 3.3 (Bruker) program. The spectra were collected in a mass range between $2,000-20,000 \mathrm{~m} / \mathrm{s}$, and then were analyzed by the MALDI Biotyper 3.1 (Bruker) program, using the standard configuration for bacteria identification, by which the spectrum of the sample is compared to the references in the database. The results vary on a 0-3 scale, where the highest value means a more precise match and reliable identification. In this study, we accepted values for matching greater than or equal to 2 as proposed by the manufacturer.

pyrH sequencing. The bacterial DNA was extracted after thermal lysis and the 541 bp pyrH fragment amplification was obtained by Polymerase Chain Reaction technique (PCR) in representative isolates to elucidate questions about the characterization of $V$. alginolyticus by validating the results found in both biochemical and proetomic techniques (Thompson et al. 2005). The concentrations used for the reactions were: buffer $10 \mathrm{X}(10 \mathrm{mM}$ Tris- $\mathrm{HCl}, \mathrm{pH} 9.0 ; 50 \mathrm{mM} \mathrm{KCl}$ 
and $0.1 \%$ Triton $\mathrm{X}-100$ ), $2.0 \mathrm{mM}$ of $\mathrm{MgCl}_{2}, 0.5 \mu \mathrm{M}$ of each primer, $0.2 \mathrm{mM}$ of dNTP (ThermoScience) and $2 \mathrm{U}$ of Taq polymerase (Kapa) in a total reaction volume of $20 \mu \mathrm{L}$ with $20 \mathrm{ng}$ of the extracted DNA. The fragments were evaluated by electrophoresis in agarose gel (1.5\%) and reveled with the SYBR green dye (Invitrogen), with the image capture system L-PIX EX (Loccus Biotecnologia). The PCR products were purified using an Exo-Sap (USB Corporation, Cleveland, Ohio), as recommended by the manufacturer and submitted to the sequencer ABI 3130xl of Applied Biosystems (Biotechnology Laboratory of the Genomic Sciences Post-Graduation Program of the Catholic University of Brasilia). The sequences were edited using the Bioedit program (Hall 1999) and Mega version 4.0 (Kumar et al. 2004) and compared with other sequences in the NCBI database (GenBank: http://www. ncbi.nlm.nih.gov/) using the BLAST algorithm (Altschul et al. 1997).

\section{RESULTS}

From the amount of 209 Vibrio spp. isolates, 49 (23\%) were phenotypically characterized as Vibrio alginolyticus. PCR amplification of the rpoA gene tested positive in all 209 isolates, corroborating the genus phenotypic identification. The MALDI-TOF MS was performed in all $49 \mathrm{~V}$. alginolyticus phenotypic identified and confirmed this identification in $87.75 \%$ $(\mathrm{n}=43)$. Four isolates were identified as Shewanella putrefaciens $(8.16 \%)$, one was identified as V. parahaemolyticus $(2.0 \%)$. and one isolate was not identified by this technique $(2.0 \%)$.

After the proteomic identification, eight representative isolates were submitted to $p y r \mathrm{H}$ gene that confirmed the results in $75 \%$. In $62,5 \%$ (85A, 11C, 6AM, 3MAC ${ }^{2}$ and $39 \mathrm{~A}$ ) of isolates, the coherence between the bioquimical tests and MALDI TOF MS technique presented the percentage of maximum identity (100\%) with $V$. alginolyticus sequences deposited in the NCBI by its pyrH sequence. One isolate (6B') was identified by phenotypic tests as V. alginolyticus, but its pyrH sequence showed $100 \%$ identity to V. parahaemolyticus, corroboring with the MALDI TOF MS technique. Only two isolates did not presented correlated data between the techniques used being isolate 30 , characterized as V. mimicus by pyrH sequence and not identified by MALDI TOF MS. Finally, one isolate (72B) identified by the proteomic technique as Shewanella putrefaciens showed $100 \%$ of identity with V. alginolyticus by pyrH sequence (Table 1 ).

\section{DISCUSSION}

The rpoA gene has been used as phylogenetic markers for bacterial classification because it is ubiquitous in bacteria, presented as a single copy and due to its resistance to lateral gene transfer. Moreover, it belongs to the bacterial core genome and although it is highly conserved among the Vibrio genus, it shows a good variability against related genera such as Grimontia, Listonella, Photobacteria and Aeromonas. (Zeigler 2003, Thompson et al. 2005). Therefore the rpoA gene detection is considered a specific, sensitive and fast method for Vibrio identification (Thompson et al. 2005, Dalmasso et al. 2009, Jeyasekaran et al. 2011).

Based on the findings in the present study, we could demonstrate that MALDI-TOF was able to identify $87.75 \%$ of the Vibrio isolate as Vibrio alginolyticus. In particular, this technique can be used as an identification tool for aquatic microorganisms. Hazen et al. (2009) used the MALDI-TOF MS to compare spectra of 10 Vibrio isolates to evaluate the discriminatory potential for V. alginolyticus, V. parahaemolyticus, $V$. harveyi and $V$. campbelli identification, since these species cannot be distinguished by $16 \mathrm{~S}$ rRNA gene analysis. Böhme et al. (2010) used MALDI-TOF MS to characterize bacterial species associated with seafoods, including Proteus, Pseudomonas, Vibrio, Serratia and Shewanella. The authors reported that this technique was able to distinguish between closely related species, contributing to the identification of marine microbiota.

In our study, the phenotypic protocol employed was able to differentiate between Vibrio species, but not to distinguish $V$. alginolyticus from S. putrefaciens, which only happened after MALDI-TOF MS analysis. In accordance with the metabolic characteristics of these microorganisms, biochemical tests able of differentiating V. alginolyticus from V. parahaemolyticus are the sucrose and arabinose fermentation and ornithine decarboxylation (Koneman et al. 2008, Noguerola \& Blanch 2008). Elliot et al. (1995) presented differential characteristics of the species frequently associated with the human disease related to the consumption of seafood. In a table demonstrated by the authors it was possible to observe the differentiation through biochemical tests of $V$. alginolyticus and V. mimicus. Shewanella putrefaciens has been described

Table 1. Identification of isolates of Vibrio alginolyticus according to phenotypic, proteomic, genotypic and biochemical tests able of differentiating the microorganisms identified by the techniques

\begin{tabular}{|c|c|c|c|c|c|}
\hline Strains & $\begin{array}{l}\text { Biochemical } \\
\text { identification }\end{array}$ & MALDI-TOF & BLASTn & $\mathrm{NCBI}^{\mathrm{a}}$ & Biochemical tests responsible for misidentification \\
\hline $6 \mathrm{~B}^{\prime}$ & V. alginolyticus & V. parahaemolyticus & V. parahaemolyticus & 0.0 & $\begin{array}{l}\text { Sucrose; arabinose fermentation, ornithine } \\
\text { descarboxylation and } \mathrm{VP}^{\mathrm{b}}\end{array}$ \\
\hline 30 & V. alginolyticus & Not identified & V. mimicus & 0.0 & $\begin{array}{l}0 \% \mathrm{NaCl}, 6 \% \mathrm{NaCl}, 8 \% \mathrm{NaCl} \text { and } 10 \% \mathrm{NaCl} \text { growth, } \mathrm{VP}^{\mathrm{b}} \text {, } \\
\mathrm{ONPG}^{\mathrm{c}}, 10 \mu \mathrm{g} 0 / 129 \text { and sucrose }\end{array}$ \\
\hline $72 \mathrm{~B}$ & V. alginolyticus & S. putrefaciens & V. alginolyticus & 0.0 & $\begin{array}{l}\text { Maltose; mannose fermentation and lysine } \\
\text { descarboxylation }\end{array}$ \\
\hline $85 \mathrm{~A}$ & V. alginolyticus & V. alginolyticus & V. alginolyticus & $6 e-178$ & - \\
\hline $11 \mathrm{C}$ & V. alginolyticus & V. alginolyticus & V. alginolyticus & 0.0 & - \\
\hline $6 \mathrm{AM}$ & V. alginolyticus & V. alginolyticus & V. alginolyticus & $6 e-178$ & - \\
\hline $3 \mathrm{MAC}^{2}$ & V. alginolyticus & V. alginolyticus & V. alginolyticus & $1 e-170$ & - \\
\hline $39 \mathrm{~A}$ & V. alginolyticus & V. alginolyticus & V. alginolyticus & 0.0 & - \\
\hline
\end{tabular}

${ }^{\mathrm{a}}$ All isolates showed maximum identity (100\%) for a species previously identified, ${ }^{\mathrm{b}} \mathrm{VP}=$ Voges-Proskauer, ${ }^{\mathrm{c}}$ ONPG $=0$-nitrophenyl-beta-Dgalactopyranoside. 
as an important bacterium in the degradation of organic compounds, especially concerning aquatic animals found in foods, sewage and estuarine/marine water (Sharma \& Kalawat 2010). V. alginolyticus and S. putrefaciens need sodium for growth, but $S$. putrefaciens can grow in NaCl-free media (Teixeira 2009). Maltose and mannose fermentation along with lysine decarboxylation are the biochemical assays able to differentiate these species (Table 1).

As mentioned above, S. putrefaciens was only identified by MALDI-TOF MS, corroborating the need to employ more precise techniques in the analysis of aquatic microbiota. MALDI-TOF MS proved to be a reliable and useful tool to understand the marine environment and its impact on animal and public health. Since 46 isolates obtained a score higher than 2, we considered this a reliable technique.

Bruker Daltonics Inc. provides a large Biotyper TM reference database for species classification. Each database entry contains a main spectrum generated from at least 20 summarized and processed single spectra of individual bacterial strains. This database was mainly generated for medical laboratory diagnostics because the main spectra largely correspond to infective bacterial species isolated from clinical samples. Therefore, this database lacks coverage of environmental strains, which has led to limited ecological studies based on wholecell MALDI-TOF MS-data (Erler et al. 2015).

In this study pyrH sequencing confirmed the proteomic results in 75\%. MALDI-TOF MS and DNA sequence-based species classifications are comparable (Alatoom et al. 2011, Rezzonico et al. 2010, Verroken et al. 2010), for instance Benagli et al. (2012) validated 93\% of MALDI-TOF MS-based Aeromonas species classifications by gyrB sequence analysis; considering that the remaining $7 \%$ were not identified because of missing reference spectra. These results corroborate also with Rodrigues et al. (2017) who observed that gyrB sequencing and the MALDI-TOF MS technique produce similar results and thus could use the proteomic technique as a "gold standard" for evaluating the sensitivity and specificity of the phenotypic tests used in enterobacteria identification. The taxonomy of vibrios has been refined in recent years and the $\mathrm{pyrH}$ (uridylate kinase) gene has been validated as a high resolution taxonomic marker. The high proportion of synonymous mutations essential for the conservation of the amino acid sequence in this gene locus allows differentiation between species. Thus, sequencing of the 541bp fragment of this gene was used for differentiation of Vibrio species (Thompson et al. 2005). In addition, this result also corroborates with Chimetto et al. (2008) that, when carrying out the taxonomic characterization of Vibrios, nitrogen-fixing cultivars associated with corals, identified V. alginolyticus through the pyrH gene sequence compared to a large database.

Monitoring and characterization of aquatic bacteria is hard and expensive work, especially due to the large number of assays that must be performed to achieve reliability. MALDI-TOF MS proved to be a very good tool for the identification of these microorganisms (Emami et al. 2012). As described by Dieckmann et al. (2010) this tecnique can be use for rapid discrimination among Vibro species specially using the Bruker Biotyper MALDI-TOF MS system. In addition, the method allowed a clear distinction to closely related bacteria such as Aeromonas spp., which are also aquatic organisms and are often present in the same environment.

\section{CONCLUSIONS}

The study showed the effectiveness of the MALDI-TOF technique for evaluation of Vibrio alginolyticus isolated from Perna Perna mussel.

As laboratories adopt MALDI-TOF mass spectrometry for routine bacterial identification, it is important to define whether or not the technology is useful for identification of specific species. The identification of environmental bacteria is difficult due to several factors, such as salinity, $\mathrm{pH}$, temperature and metabolic diversity. In the present study, the results of the MALDI-TOF MS technique corresponded to $87.75 \%$ with the results of the phenotypic test, being very efficient to distinguishing $V$. alginolyticus from the closely related species $V$. parahaemolyticus.

The pyrH gene sequencing confirmed the proteome results in $75 \%$, validating this technique as a high potential for routine automated analysis, allowing the identification of isolates from clinical and environmental sources on a large scale. It is also a quick and easy method with high specificity and sensitivity.

Conflict of interest statement.- The authors have no competing interests.

Acknowledgements.- The authors are grateful to Larissa A.B. Botelho, Beatriz M. Moreira and the Coordination of Improvement of Higher Education Personnel (CAPES) for financial and technical support of this study.

\section{REFERENCES}

Alatoom A.A., Cunningham S.A., Ihde S.M., Mandrekar J. \& Patel R. 2011. Comparison of direct colony method versus extraction method for identification of gram-positive cocci by use of Bruker Biotyper matrixassisted laser desorption ionization-time of flight mass spectrometry. J. Clin. Microbiol. 49(8):2868-2873.<http://dx.doi.org/10.1128/JCM.0050611> <PMid:21613431>

Altschul S.F., Madden T.L., Schäffer A.A., Zhang J., Zhang Z., Miller W. \& Lipman D.J. 1997. Gapped BLAST and PSI-BLAST: a new generation of protein database search programs. Nucleic Acids Res. 25(17):3389-3402.<http:// dx.doi.org/10.1093/nar/25.17.3389><PMid:9254694>

Barbuddhe S.B., Maier T., Schwarz G., Kostrzewa M., Hof H., Domann E., Chakraborty T. \& Hain T. 2008. Rapid identification and typing of Listeria species by matrix-assisted laser desorption ionization-time of flight mass spectrometry. Appl. Environ. Microbiol. 74(17):5402-5407.<http://dx.doi. org/10.1128/AEM.02689-07> <PMid:18606788>

Bauer A. \& Rørvik L.M. 2007. A novel multiplex PCR for the identication of Vibrio parahaemolyticus, Vibrio cholera and Vibrio vulnificus. Lett. Appl. Microbiol. 45(4):371-375. <http://dx.doi.org/10.1111/j.1472765X.2007.02195.x> <PMid:17897378>

Benagli C., Demarta A., Caminada A., Ziegler D., Petrini O. \& Tonolla M. 2012. A rapid MALDI-TOF MS identification database at genospecies level for clinical and environmental Aeromonas strains. PLoS One 7(10):e48441. <http://dx.doi.org/10.1371/journal.pone.0048441><PMid:23119019>

Böhme K., Fernandez-No I.C., Barros-Velazquez J., Gallardo J.M., Calo-Mata P. \& Cañas B. 2010. species differentiation of seafood spoilage and pathogenic gram- negative bacteria by MALDI-TOF mass fingerprinting. J. Proteome Res. 9(6):3169-3183. <http://dx.doi.org/10.1021/pr100047q> <PMid:20408567>

Bruyne K., Slabbinck B., Waegeman W., Vauterin P., Baets B. \& Vandamme P. 2011. Bacterial species identification from MALDI-TOF mass spectra through data analysis and machine learning. System. Appl. Microbiol. 34(1):20-29. <http://dx.doi.org/10.1016/j.syapm.2010.11.003> <PMid:21295428> 
Carbonnelle E., Beretti J.L., Cottyn S., Quesne G., Berche P., Nassif X. \& Ferroni A. 2007. Rapid identification of staphylococci isolated in clinical microbiology laboratories by Matrix-Assisted Laser Desorption Ionization-Time of Flight Mass Spectrometry. J. Clin. Microbiol. 45(7):2156-2161. <http://dx.doi. org/10.1128/JCM.02405-06><PMid:17507519>

Cash P. 2011. Investigating pathogen biology at the level of proteome. Proteomics 11(15):3190-3202. <http://dx.doi.org/10.1002/pmic.201100029> <PMid:21726048>

Cavallo R.A. \& Stabili L. 2002. Presence of Vibrio in seawater and Mytilus galloprovincialis (Lam.) from the Mar Piccolo of Taranto (Ionian Sea). Water Research 36(15):3719-3726. <http://dx.doi.org/10.1016/S00431354(02)00107-0> <PMid:12369519>

CDC 2012. National Cholera and Vibriosis Surveillance: Cholera and other Vibrio llness Surveillance (COVIS) Annual Summary. Centers for Disease Control and Prevention, Atlanta. Available at <http://www.cdc.gov/ nationalsurveillance/choleravibrio-surveillance.html> Access on July 20, 2017.

Chimetto L.A., Brocchi M., Thompson C.C., Martins R.C.R., Ramos H.B. \& Thompson F.L. 2008. Vibrios dominate as culturable nitrogen-fixing bacteria of Brazilian coral Mussismulia hispida. System. Appl. Microbiol. 31(4):312319. <http://dx.doi.org/10.1016/j.syapm.2008.06.001><PMid:18678453>

Dalmasso A., Civera T. \& Bottero M.T. 2009. Multiplex primer-extension assay for identification of six pathogenic vibrios. Int. J. Food Microbiol 129(1):21-25. <http://dx.doi.org/10.1016/j.ijfoodmicro.2008.10.029> $<$ PMid:19070382>

Dieckmann R., Strauch E. \& Alter T. 2010. Rapid identification and characterization of Vibrio species using whole-cell MALDI-TOF mass spectrometry. J. Appl. Microbiol. 109(1):199-211. <PMid:20059616>

Dieckmann R., Helmuth R., Erhard M. \& Malorny B. 2008. Rapid classification and identification of Salmonellae at the species and subspecies levels by whole-cell matrix-assisted laser desorption ionization-time of flight mass spectrometry. Appl. Environ. Microbiol. 74(24):7767-7778. <http://dx.doi. org/10.1128/AEM.01402-08><PMid:18952875>

Elliot E.L., Kaysner C.A., Jackson L. \& Tamplin M.L. 1995. Vibrio cholerae, V. parahaemolyticus, V. vulnificus and other Vibrio spp., p.9.01-9.27. In: Andrews W.H., June G.A., Sherrod P.S., Hammack T.S. \& Amaguana R.M., FDA Bacteriological Analytical Manual. 8th ed. AOAC International, Gaithersburg, MD.

Emami K., Askari V., Ullrich M., Mohinudeen K., Anil A.C., Khandeparker L., Burgess J.G. \& Mesbahi E. 2012. characterization of bacteria in ballast water using MALDI-TOF Mass Spectrometry. PLoS One 7(6):e38515. <http://dx.doi.org/10.1371/journal.pone.0038515><PMid:22685576>

Erler R., Wichels A., Heinemeyer E.A., Hauk G., Hippelein M., Reyes N.T. \& Gerdts G. 2015. VibrioBase: a MALDI-TOF MS database for fast identification of Vibrio spp. that are potentially pathogenic in humans. System. Appl. Microbiol. 38(1):16-25. <http://dx.doi.org/10.1016/j.syapm.2014.10.009> $<$ PMid:25466918>

FDA 2004. Bacteriological Analytical Manual. Food and Drug Administration, Maryland. Available at <http://www.cfsan.fda.gov/ ebam/bam-9.html> Access on July 20, 2017

Gilbride K.A., Lee D.Y. \& Beaudette L.A. 2006. Molecular techniques in wastewater: understanding microbial communities, detecting pathogens and real-time process control. J. Microbiol. Methods 66(1):1-20. <http:// dx.doi.org/10.1016/j.mimet.2006.02.016> <PMid:16635533>

Haley B.J., Grim C.J., Hasan N.A., Choi S.Y., Chun J., Brettin T.S., Bruce D.C., Challacombe J.F., Detter J.C., Han C.S., Huq A. \& Colwell R.R. 2010 Comparative genomic analysis reveals evidence of two novel Vibrio species closely related to V. cholerae. BMC Microbiol. 10(1):154. <http://dx.doi. org/10.1186/1471-2180-10-154><PMid:20507608>

Hall T.A. 1999. BioEdit: a user-friendly biological sequence alignment editor and analysis program for Windows 95/98/NT. Nucl. Acids, Symp. Ser. 41:95-98.
Hazen T.H., Martinez R.J., Chen Y., Lafon P.C., Garrett N.M., Parsons M.B., Bopp C.A., Sullards M.C. \& Sobecky P.A. 2009. Rapid identification of Vibrio parahaemolyticus by whole-cell Matrix-Assisted Laser Desorption ionizationtime of flight mass spectrometry. Appl. Environ. Microbiol. 75(21):67456756. <http://dx.doi.org/10.1128/AEM.01171-09><PMid:19749061>

Ilina E.N., Borovskaya A.D., Malakhova M.M., Vereshchagin V.A., Kubanova A.A., Kruglov A.N., Svistunova T.S., Gazarian A.O., Maier T., Kostrzewa M. \& Govorun V.M. 2009. Direct bacterial profiling by Matrix-Assisted Laser Desorption-Ionization Time-of-Flight Mass Spectrometry for identification of pathogenic Neisseria. J. Molecular Diagnostics 11(1):75-86. <http:// dx.doi.org/10.2353/jmoldx.2009.080079> <PMid:19095774>

Jeyasekaran G., Thirumalai Raj K., Jeya Shakila R., Jemila Thangarani A. \& Sukumar D. 2011. Multiplex polymerase chain reaction-based assay for the specific detection of toxin-producing Vibrio cholerae in fish and fishery products. Appl. Microbiol. Biotechnol. 90(3):1111-1118. <http://dx.doi. org/10.1007/s00253-011-3175-9><PMid:21360148>

Koneman E., Winn W.J., Allen S., Janda W., Procop G., Schreckenberger P. \& Woods G. 2008. Koneman's Color Atlas and Text Book of Diagnostic Microbiology. 6th ed. Lippincott Williams and Wilkins, Philadelphia, p.387-422.

Kong W., Huang L.X., Su Y.Q., Qin Y.X., Ma Y., Xu X.J., Lin M., Zheng J. \& Yan Q. 2015. Investigation of possible molecular mechanisms underlying the regulation of adhesion in Vibrio alginolyticus with comparative transcriptome analysis. Antonie van Leeuwenhoek 107(5):1197-1206. <http://dx.doi. org/10.1007/s10482-015-0411-9><PMid:25726081>

Kumar S., Tamura K. \& Nei M. 2004. MEGA3: integrated software for molecular evolutionary genetics analysis and sequence alignment. Briefings in Bioinformatics 5(2):150-163. <http://dx.doi.org/10.1093/bib/5.2.150> $<$ PMid:15260895>

Lasch P., Beyer W., Nattermann H., Stammler M., Siegbrecht E., Grunow R. \& Naumann D. 2009. Identification of Bacillus anthracis by using MatrixAssisted Laser Desorption Ionization-Time of Flight Mass Spectrometry and Artificial Neural Networks. Appl. Environ. Microbiol. 75(22):72297242. <http://dx.doi.org/10.1128/AEM.00857-09><PMid:19767470>

Li C.C. \& Chen J.C. 2008. The immune response of white shrimp Litopenaeus vannamei and its susceptibility to Vibrio alginolyticus under low and high pH stress. Fish Shellfish Immunol. 25(6):701-709. <http://dx.doi. org/10.1016/j.fsi.2008.01.007><PMid:18990589>

López-Hernández K.M., Pardío-Sedas V.T., Lizárraga-Partida L., Williams J.D.J., Martínez-Herrera D., Flores-Primo A., Uscanga-Serrano R. \& RendónCastro K. 2015. Environmental parameters influence on the dynamics of total and pathogenic Vibrio parahaemolyticus densities in Crassostrea virginica harvested from Mexico's Gulf coast. Marine Pollution Bulletin 91(1):317-329. <http://dx.doi.org/10.1016/j.marpolbul.2014.11.015> $<$ PMid:25510545>

Makino K., Oshima K., Kurokawa K., Yokoyama K., Uda T., Tagomori K., Iijima Y., Najima M., Nakano M., Yamashita A., Kubota Y., Kimura S., Yasunaga T., Honda T., Shinagawa H., Hattori M. \& Iida T. 2003. Genome sequence of Vibrio parahaemolyticus: a pathogenic mechanism distinct from that of $V$. cholerae. Lancet 361(9359):743-749. <http://dx.doi.org/10.1016/ S0140-6736(03)12659-1><PMid:12620739>

Nagy E., Maier T., Urban E., Terhes G. \& Kostrzewa M. 2009. Species identification of clinical isolates of Bacteroides by matrix-assisted laser-desorption/ionization time-of-flight mass spectrometry. Clin. Microbiol. Infection 15(8):796-802. <http://dx.doi.org/10.1111/j.1469-0691.2009.02788.x><PMid:19438622>

Noguerola I. \& Blanch A.R. 2008. Identification of Vibrio spp. with a set of dichotomous keys. J. Appl. Microbiol. 105(1):175-185. <http://dx.doi. org/10.1111/j.1365-2672.2008.03730.x><PMid:18248367>

Penque D. 2009. Two-dimensional gel electrophoresis and mass spectrometry for biomarker discovery. Proteomics Clin. Applications 3(2):155-172. <http://dx.doi.org/10.1002/prca.200800025><PMid:26238616>

Rezzonico F., Vogel G., Duffy B. \& Tonolla M. 2010. Application of whole-cell matrix-assisted laser desorption ionization-time of flight mass spectrometry 
for rapid identification and clustering analysis of Pantoea species. Appl. Environ. Microbiol. 76(13):4497-4509. <http://dx.doi.org/10.1128/ AEM.03112-09><PMid:20453125>

Rodrigues N.M., Bronzato G.F., Santiago G.S., Botelho L.A., Moreira B.M., Coelho I.D., Souza M.M. \& Coelho S.M. 2017. The Matrix-Assisted Laser Desorption Ionization-Time of Flight Mass Spectrometry (MALDI-TOF MS) identification versus biochemical tests: a study with enterobacteria from a dairy cattle environment. Braz. J. Microbiol. 48(1):132-138. <http:// dx.doi.org/10.1016/j.bjm.2016.07.025><PMid:27818092>

Scallan E., Hoekstra R.M., Angulo F.J., Tauxe R.V., Widdowson M.A., Roy S.L., Jones J.L. \& Griffin P.M. 2011. Foodborne illness acquired in the united states major pathogens. Emerg. Infect. Dis. 17(1):7-15. <http://dx.doi. org/10.3201/eid1701.P11101><PMid:21192848>

Sewell D.L. 2002. Bacteriology, p.1074-1124. In: Kenneth D. \& McClatchey (Eds), Clinical Laboratory Medicine. 2nd ed. Lippincott Willians and Wilkins, Philadelphia.

Sganga G., Cozza V., Spanu T., Spada P.L. \& Fadda G. 2009. Global climate change and wound care: case study of an off-season Vibrio alginolyticus infection in a healthy man. Ostomy Wound Manage. 55(4):60-62.<PMid:19387097>

Sharma K.K. \& Kalawat U. 2010. Emerging infections: Shewanella-a series of five cases. J. Lab. Physicians 2(2):61-65. <http://dx.doi.org/10.4103/09742727.72150><PMid:21346897>

Srinivasan S. \& Kjelleberg S. 1998. Cycles of famine and feast: the starvation and outgrowth strategies of a marine Vibrio. J. Biosciences 23(4):501-511. <http://dx.doi.org/10.1007/BF02936144>

Stryer L., Tymoczko J.L. \& Berg J.M. 2007. Biochemistry. 6th ed. W.H. Freeman and Company, USA. 1026p.

Sur D., Dutta S., Sarkar B.L., Manna B., Bhattacharya M.K., Datta K.K., Saha A., Dutta B., Pazhani G.P., Choudhuri A.R. \& Bhattacharya S.K. 2007. Occurrence, significance \& molecular epidemiology of cholera outbreaks in West Bengal. Indian J. Med. Res. 125(6):772-776. <PMid:17704555>

Tarr C.L., Patel J.S., Puhr N.D., Sowers E.G., Bopp C.A. \& Strockbine N.A.A. 2007. Identification of Vibrio isolates by a multiplex PCR assay and $r p o B$ sequence determination. J. Clin. Microbiol. 45(1):134-140.<http://dx.doi. org/10.1128/JCM.01544-06><PMid:17093013>

Teixeira C.E. 2009. Evaluation of the combined effect of the processes of irradiation and modified in bacteriological, physico-chemical and sensory quality of the file tilapia (O. niloticus) cold atmosphere. Doctoral Thesis, Federal Fluminense University, Niterói.

Thompson F.L., Iida T. \& Swings J. 2004. Biodiversity of Vibrios. Microbiol. Molec. Biol. Rev. 68(3):403-431. <http://dx.doi.org/10.1128/MMBR.68.3.403431.2004> <PMid:15353563>

Thompson F.L., Gevers D., Thompson C.C., Dawyndt P., Naser S., Hoste B., Munn C.B. \& Swings J. 2005. Phylogeny and molecular identification of vibrios on the basis of multilocus sequence analysis. Appl. Environ.
Microbiol. 71(9):5107-5115.<http://dx.doi.org/10.1128/AEM.71.9.51075115.2005><PMid:16151093>

Van Schaik W. \& Willems R.J.L. 2010. Genome-based insights into the evolution of enterococci. Clin. Microbiol. Infect. 16(6):527-532. <http://dx.doi. org/10.1111/j.1469-0691.2010.03201.x> <PMid:20569263>

Verroken A., Janssens M., Berhin C., Bogaerts P., Huang T.D., Wauters G. \& Glupczynski Y. 2010. Evaluation of matrix-assisted laser desorption ionization-time of flight mass spectrometry for identification of Nocardia species. J. Clin. Microbiol. 48(11):4015-4021. <http://dx.doi.org/10.1128/ JCM.01234-10><PMid:20861335>

Wang L.U. \& Chen J.C. 2005. The immune response of white shrimp Litopenaeus vannamei and its susceptibility to Vibrio alginolyticus at different salinity levels. Fish Shellfish Immunol. 18(4):269-278. <http://dx.doi.org/10.1016/j. fsi.2004.07.008> <PMid:15561558>

Wang Q., Liu Q., Cao X., Yang M. \& Zhang Y. 2008. Characterization of two TonB systems in marine fish pathogen Vibrio alginolyticus: their roles in iron utilization and virulence. Archs Microbiol. 190(5):595-603. <http:// dx.doi.org/10.1007/s00203-008-0407-1><PMid:18629473>

Wang S.X., Wei J.T. \& Li T.B. 2012. Susceptibility of a Vibrio alginolyticus rpoS mutant to environmental stresses and its expression of OMPs. J. Basic Microbiol.52(4):467-476. <http://dx.doi.org/10.1002/jobm.201100249> $<$ PMid:22052546>

WHO 2013/2014. Cholera. Wkly Epidemiol. Rec. 89:345-356. Available at <http://www.who.int/cholera/statistics/en/> Access on July 20, 2017.

Yeh S.T., Li C.C., Tsui W.C., Lin Y.C. \& Chen J.C. 2010. The protective immunity of white shrimp Litopenaeus vannamei that had been immersed in the hot-water extract of Gracilaria tenuistipitata and subjected to combined stresses of Vibrio alginolyticus injection and temperature change. Fis Shellfish Immunol. 29(2):271-278. <http://dx.doi.org/10.1016/j.fsi.2010.04.014> $<$ PMid:20420916>

Yi J.B., Chen Q., Zou W.Z., Yan Q.P., Zhuang Z.X. \& Wang X.R. 2008. Starvation effects on pathogenic Vibrio alginolyticus in natural seawater. Acta Oceanologica Sinica 27:120-129.

Yoder J.S., Hlavsa M.C., Craun G.F., Hill V., Roberts V., Yu P.A., Hicks L.A., Alexander N.T., Calderon R.L., Roy S.L. \& Beach M.J. 2008. Surveillance for waterborne disease and outbreaks associated with recreational water use and other aquatic facility-associated health events-United States, 2005/2006. MMWR Surveillance Summary 57(9):1-29. <PMid:18784642>

Zeigler D.R. 2003. Gene sequences useful for predicting relatedness of whole genomes in bacteria. Int. J. Syst. Evol. Microbiol. 53(Pt 6):1893-1900. <http://dx.doi.org/10.1099/ijs.0.02713-0><PMid:14657120>

Zhenyu X., Shaowen K., Chaoqun H., Zhixiong Z., Shifeng W. \& Yongcan Z. 2013. First characterization of bacterial pathogen, Vibrio alginolyticus, for Porites andrewsi white syndrome in the South China Sea. PLoS One 8(9):e75425. <http://dx.doi.org/10.1371/journal.pone.0075425><PMid:24086529> 